\title{
Recent Business and Human Rights Brazilian Regulation
}

\author{
Danielle Mendes Thame Denny ${ }^{1,2}$ (1) \\ ${ }^{1}$ University College London, London, UK \\ ${ }^{2}$ Fundação Armando Álvares Penteado and Universidade Paulista, São Paulo, Brazil \\ Email: danielle.denny@gmail.com
}

How to cite this paper: Denny, D. M. T. (2019). Recent Business and Human Rights Brazilian Regulation. Beijing Law Review, 10, 643-655.

https://doi.org/10.4236/blr.2019.104036

Received: May 7, 2019

Accepted: July 5, 2019

Published: July 8, 2019

Copyright (c) 2019 by author(s) and Scientific Research Publishing Inc. This work is licensed under the Creative Commons Attribution International License (CC BY 4.0).

http://creativecommons.org/licenses/by/4.0/

\begin{abstract}
The recent Brazilian decree about Business and Human Rights may have a significant impact on the international trade, because it will construct the companies' actions in the country. Business relations will probably face the need of compliance with due diligence mechanisms. This paper aims to shed light over some probable conflicts, using the deductive methodology from Brazil's legal texts and jurisprudence.
\end{abstract}

\section{Keywords}

Business and Human Rights, Brazil, International Trade

\section{Introduction}

Human rights legal regimes were originally thought to limit abuses committed by States against individuals. Their legal roots were International Law treaties or declaration, where the actors used to be only national states, and member states, in case of an agreement within an international organization (Abbott \& Snidal, 2000). The increasingly global presence of companies has altered this equation, since the 1970s and on an upward direction in the current global chain production economy.

According to data systematized by Global Justice Now, companies are in the position of tilting the balance of power in many ways ("Global Justice Now," 2018). From a direct comparison between the annual revenues of the companies and the annual revenues of the countries, among the 100 largest economies in the world, 69 were companies in the year 2017 ("Global Justice Now," 2018). The tenth economy of the world would be Walmart if companies would count with countries, being ahead of countries like Spain and Australia for example. 
The digital revolution has the misfortune of unfolding in a neo-liberal era that has been shredding the social contract. In such context, simply pledging to leave no one behind like Agenda $2030 \mathrm{did}$ (UN, 2015) appealing to the goodwill of corporations or the charity of the super-rich is, "at best, hopeful pleas for a more civic world and, at worst, willful attempts to deflect from serious discussion of the real factors driving growing inequality, indebtedness and insecurity" (UNCTAD, 2018: p. 26).

The inequality of the system is one of the main points of distress. The five largest exporting firms accounted for around 30 percent of a country's total exports, and the 10 largest exporting firms for 42 percent (UNCTAD, 2018: p. 5). These economic titans, one can suppose, tend to be above social and political accountability, because national constituencies and labour force praise them around the world as wealth creators.

But the strategies of transnational corporations to capture value in global value chains (GVCs) are designed on their own terms, with high value-added inputs and protected intellectual property content sold at high prices to processing exporters (UNCTAD, 2018: p. 5). Developing countries, if successful to attract those titans, account for only a tiny fraction of the value of exported final goods. One rare exception has been China which unique path in promoting economic development "has made outstanding contributions to safeguarding a just world order" (Ren, 2018).

This asymmetrical power of some companies means, in practice, the potentiality both of causing positive impacts and of causing profound negative impacts. What is expected is that, through tools such as due diligence in human rights, companies can be led to maximize the positive effects.

One guideline to be following in this direction is the Guiding Principles on Business and Human Rights (HRC, Human Rights Council, 2011), approved by the United Nations Human Rights Council in 2011. It comprised 31 principles that establish it is mandatory to respect human rights in all commercial relations and business operations, whether conducted by private or public agents.

Under the legal perspective, the main innovation brought by the Guiding Principles was to establish that what was international law, materialized in declarations and treaties were also applied to companies. Countries were adamant about human rights in many opportunities such as the Universal Declaration of Human Rights (UN, 1948), the International Covenant on Civil and Political Rights (UN, 1966a), the International Covenant on Economic, Social and Cultural Rights (UN, 1966b).

Also the formations of the international system for protecting these rights were designed by and to states. There is a legal gap to companies to act and assume responsibilities in these systems. Therefore, what can be expected from them is that through tools such as due diligence in human rights, companies can prevent the risks and adverse impacts of human rights and remedy violations related to operations, products or services, including along their international supply chain. 
The Brazilian Decree No. 9571 (Brasil, 2018), published on November 21st, 2018 was in this direction. It established the National Guidelines on Business and Human Rights, to operationalize the protection and respect for human rights in business, establishing commitments for the State and for companies, as well as forms to access repair and remediation mechanisms for those who have their rights violated.

In this sense, there are some good initiatives such as, the obligation of the State to develop public policies and changes in the legal system to consider the impacts of companies in supply chains, as well as prioritize reparations and compensation for vulnerable groups; the encouragement of the adoption of risk prevention tools by companies; or the improvement of mechanisms of transparency and social participation that can guarantee access to remediation (Brasil, 2018).

If, on the one hand, the content of the Decree could take Brazil a step further in the application of human rights to companies, and this is what is expected of the states that have committed themselves to adopt the Agenda 2030 (UN, 2015), on the other hand, its art. 1 st, $\$ \$ 1$ and 2 inserted a way of minimizing corporate responsibility. The bill clearly states that the guidelines will be implemented voluntarily by companies and also assigns a stamp, a prize, to companies that fulfil their obligation to respect human rights.

But the human rights discourse suggests that deprivations must be ended right away with top priority remedial attention, this does not fit in a voluntary and incremental approach (Pogge \& Sengupta, 2016; Pogge, Kaul, Kim, Västfjäll, \& Slovic, 2015). Human rights brook no delay, once we recognize a human right we must initiate the necessary institutional reforms right away (Pogge \& Sengupta, 2016: p. 85). Supranational rule making is not a morality-free zone in which it is acceptable for government representatives to strike bargains for mutual advantage, those rules, notably in the economic sphere, have profound effects on human rights fulfillment around the world (Pogge et al., 2015: p. 38).

\section{UN Guiding Principles and the First Draft}

The UN Guiding Principles on Business and Human Rights (HRC, Human Rights Council, 2011) is one of the international documents ${ }^{1}$ that inspired the Brazilian decree.

Article 5 Companies shall be responsible for:

1) monitor respect for human rights in the production chain linked to the company;

2) internally disseminate the international instruments of social responsibility and human rights, such as:

a) the United Nations Organization Guiding Principles on Business and $\mathrm{Hu}-$ man Rights;

b) the Guidelines for Multinationals of the Organization for Economic Coop-

${ }^{1}$ The others are the OECD's (OECD, 2011; Nieuwenkamp, 2013) and ILO's (ILO, 1919, 2017) guidelines. 
eration and Development; and

c) the Conventions of the International Labor Organization.

3) implement educational activities in human rights for its human resources and its collaborators, with dissemination of national legislation and international parameters, focusing on norms relevant to the practice of individuals and risks to human rights;

4) use education, awareness and training mechanisms, such as courses, lectures and appraisals of learning, so that its managers, employees, employees, distributors, business partners and third parties know the values, norms and policies of the company and know their role for the success of the programs; and

5) draw up a publicly accessible code of conduct approved by the company's senior management, which will contain its commitments and its human rights implementation policies in business activity. ${ }^{2}$

Also known as Ruggie Principles, because of the UN Special Representative, John Ruggie, who proposed the framework. They were drafted in a context in which the United Nations sought to respond to the demands of member states and also of various social movements and civil society organizations representing the interests of who were affected by human rights violations and who suffered from a lack of adequate protection to confront the power transnational corporations had in their countries.

There was recognized promiscuous relations between companies and states, which made the latter often connive with corporations, creating a "space of exception", conducive to violations of the rights of local populations (Homa et al., 2018). If regulation do not intervene the liberal logic characteristic of transnational capital tend to lead to the association between companies and states in order to generate greater advantages for cross-border investments.

There is an expression to this sort of deleterious association: "race to the bottom", which defines a tendency of States, especially in the global south, to grant certain incentives to transnational corporations to have established in their territories as a way to obtain economic benefits or competitive advantages (Homa et al., 2018). This means, they grant from tax exemptions to advantageous sources of financing, which, to a great extent, are linked to the weakening of in${ }^{2}$ Free translation of the Brazilian legal text: “Art. $5^{\circ}$ Caberá, ainda, às empresas: 1) monitorar o respeito aos direitos humanos na cadeia produtiva vinculada à empresa; 2) divulgar internamente os instrumentos internacionais de responsabilidade social e de direitos humanos, tais como: a) os Princípios Orientadores sobre Empresas e Direitos Humanos da Organização das Nações Unidas; b) as Diretrizes para Multinacionais da Organização para a Cooperação e Desenvolvimento Econômico; e c) as Convenções da Organização Internacional do Trabalho; 3) implementar atividades educativas em direitos humanos para seus recursos humanos e seus colaboradores, com disseminação da legislação nacional e dos parâmetros internacionais, com foco nas normas relevantes para a prática dos indivíduos e os riscos para os direitos humanos; 4) utilizar mecanismos de educação, de conscientização e de treinamento, tais como cursos, palestras e avaliações de aprendizagem, para que seus dirigentes, empregados, colaboradores, distribuidores, parceiros comerciais e terceiros conheçam os valores, as normas e as políticas da empresa e conheçam seu papel para o sucesso dos programas; e 5) redigir código de conduta publicamente acessível, aprovado pela alta administração da empresa, que conterá os seus engajamentos e as suas políticas de implementação dos direitos humanos na atividade empresarial." 
struments for the exercise of the monitoring role of the State on the performance of business activity and also the direct easing of human rights protection standards (Homa et al., 2018). Companies, on the other hand, are attracted to locations where profits will be greater, and the risk of being held accountable for human rights violations will be lower.

In terms of competition, ethical companies suffer with the lack of fair play, when competing with those that practices an artificially cheaper price because they neglect their social and environmental responsibilities; this misconduct can be defined as social environmental dumping (Kessie \& UNCTAD, 2003; UNCTAD, 2003). Because of that, many companies themselves demand for stringent international regulations (Denny, 2018b). "High performance with high integrity" (Baumann-Pauly \& Nolan, 2016: p. 88) can be the key to global business success. Besides being morally wrong, human rights neglecting can cost market access in the current governance system oriented by corporate social environmental governance, which measures ethics broadly through governmental, private, national, foreign, mandatory or voluntary strategies (Denny, 2018b).

Parallel to that, the process of creating an international legally binding instrument to regulate, under international law and the UN, the activities of transnational corporations and other business enterprises with respect to human rights have been also moving forward (Rivera, 2018).

Prevention is the first pillar of the First Draft incorporating the Guiding Principles. Access to justice at the victim's country or where the company is incorporated is the second pillar. International cooperation is the third pillar. Monitoring mechanisms, the fourth. Inspiration had been drawn from other human rights treaties.

Decrees, rules, standards, procedures and others institutional arrangements are not "living accountable creatures who could be expected to conform themselves to moral standards" rather they reflect the human agents interests who "formulate, shape, design, interpret, apply, enforce, obey, violate, undermine or ignore them" (Pogge et al., 2015: p. 51).

\section{Brazilian Decree Business and Human Rights}

\subsection{Voluntary Standards}

The Brazilian Decree establishes guidelines are voluntary and therefore the fulfilment of human rights may or may not occur is a political, legal, social and economic regression since several foreign laws, as in the case of the English Modern Loan Act or Loi no. 399/2017 were recently adopted to demand that companies that market in their countries adopt mechanisms of control and accountability on the respect of human rights, including considering its supply chain (Acca \& Scabin, 2018).

In view of the need to legally binding regulation and to create mechanisms to hold transnational corporations accountable for human rights violations, the Corporate Social Responsibility aspect, based on voluntary measures, has little 
effectiveness, besides generating positive marketing for the companies and being comparable to philanthropic activities (Homa, Roland, \& Lima, 2018: p. 9).

On the other hand partnerships between multi-stakeholder can be more efficient to achieve cooperation and solve problems. And voluntarily initiatives undertaken by business, governments, intergovernmental organizations, major groups and others stakeholders in smaller scale but more abundantly can contribute more to the implementation of what is considered Human Rights responsibilities to companies (Denny, 2018b).

This because, to reflect the reality of GVC, legal relations, especially those related to International Economic Law, increasingly involve problems arising from the interaction between public and private persons of different nationalities. It is from this national, international, public and private intersection that methodologies of standard analysis may be better systematized to deal with problems that have transnational aspects like human rights violations. Regulation needs to be agile and pragmatic in order to be effective in a business environment based on global value chains, in which gains from convergence, coherence and regulatory cooperation are essential to ensure competitiveness (Thorstensen \& Badin, 2017).

The quality of a process in GVC comes from the fact that production takes place in stages that add value to products. At each stage, the producer acquires its inputs and employs production factors. The payment of these factors will set the value added to the product. The process is repeated at the next stage so that the former becomes the value added to the next producer. One or several companies within and outside the country, creating a production chain, may perform a set of steps into this production process.

In this context, voluntary standards are efficient to articulate this new institutionalism, focused on governance (Denny, 2018a: p. 64). They play three roles simultaneously: replacing inadequate public regulation, responding to increasingly stringent regulations in areas such as environmental regulation, and being a way to overcome public regulations asymmetries therefore providing systematic basis for product differentiation.

To a large extent, the rise in the development of private standards can be perceived as a response to the regulatory measures implemented by some markets such as the European and the American. And they are part of a broader trend in value chain coordination, in the context of on-going changes in regulatory controls, consumer demand, and multi-stakeholder and pragmatic governance that is needed in international trade.

Private standards can assume one of the four possible combinations in the public/private and compulsory/voluntary regulatory scheme, according to Henson and Humphrey: A1) regulations containing mandatory public standards; B1) voluntary public norms: standards that are created by public bodies, but whose adoption is voluntary; C1) standards developed by the private sector that are then made mandatory by public authorities; and D1) voluntary private standards: developed and implemented by private bodies (Henson \& Humphrey, 
2010: p. 1631).

Voluntary private standards are also designated market standards or sustainability standards. Market standards are those originated from business or independent bodies and can be different from the international private standards that are elaborated within recognized bodies, such as the International Organization for Standardization-ISO.

Private standards are international standards with non-governmental characteristic but they can be recognized by governments and then be accommodated within the multilateral trading system, for example, like it is done in the Technical Barriers to Trade or the Agreement on the Application of Sanitary and Phytosanitary Measures Agreements. Despite their voluntary nature, such standards can become indeed practically very mandatory for those willing to access certain regulated market and also when recognized by governments they may even be submitted to the TBT and SPS Committees for public periodically reviews (Thorstensen, Kotzias, \& Vieira, 2015: p. 2).

To companies competing in global value chain, compliance with voluntary sustainability standards can represent a markup price on goods and services certified and labelled because it indicates better quality, it also increase the marketability of sustainable exports to the growing and lucrative responsible markets. And in some high-regulated markets the compliance is even a condition to market access.

Complying with these standards can also contribute to better and more effective manage the production and distribution, putting in place more sustainable methods, in the aggregate scale means many enterprises doing so locally, contributing to the achievement of the guidelines globally.

Voluntary private standards have basically five functions to perform: A2) formulate the operational procedures of a standard; B2) decide on whether or not to adopt a standard; C2) implement the intended rule from compliance procedures, D2) conformity assessment to verify that those who claim to comply with the standard can provide documentary evidence to prove compliance with the standards; and E2) certification, recommendation of corrective measures or discrediting if there is no conformity (Henson \& Humphrey, 2010: p. 1631).

In addition, there is a thematic division: A3) standards related to food security; B3) regulations requiring compliance with environmental and social standards; C3) technical and quality standards; and, finally, D3) normative regulatory framework, regarding best practices for the development of voluntary private standards (Henson \& Humphrey, 2010: p. 1631).

Voluntary sustainability standards can be a useful and widespread market-based tool that enables businesses and stakeholders to assess the conformity of commodity production, supply chain management and consumption patterns to the human rights guidelines, and doing so to improve production becoming more accountable. In this sense the guidelines will set a baseline but they can also justify a waiver to those forever in process of complying and never actually committing to pragmatic measures. The new Brazilian decree is not different. 


\subsection{Protection against Drawbacks but Other Risks}

This dichotomy can be pointed out in many ways. Responsibility to respect human rights is the minimum that is expected of all companies. With the recent change in Brazilian government from a left oriented to a far right since 2019, interpretation about what is human rights and the means to enforce it can vary. In this sense the decree is a positive initiative to reinforce some basic level play to all companies doing business in Brazil.

To contextualise, it is relevant to go through the UN High Commissioner for Human Rights three types of access to remedy. The first one is judicial mechanisms that comprise the court systems applying the laws to enforce "public law offences (e.g., criminal matters) and decide private law claims for remedies by affected individuals and communities (e.g., civil actions)" (OHCHR, 2018: p. 4). The second are state-based non-judicial grievance mechanisms, such as public mechanisms typically administered by the executive (i.e., ministerial) branch of government (not courts). These administrative processes are accessible by individuals whose human rights have been adversely impacted by business activities in order to seek a remedy. And the third, the non-state-based grievance mechanisms that may encompass company-based or multi-stakeholder based grievance mechanisms, as well as regional and international human rights bodies (e.g., trade unions, industry association or a multi-stakeholder group) (OHCHR, 2018: p. 4).

The Brazilian decree is based on these axes, and includes public and corporate responsibility, access to remediation mechanisms as well as monitoring and evaluation strategies of compliance with the guidelines. Some of the auspicious devices created by the decree are the inclusion of supply chains as possible culprit of corporate-led violations. Another point important to mention is the priority given for reparations and compensation for vulnerable groups, and the need to improve mechanisms for transparency and participation.

Art. 2 The guiding axes of the National Directives on Business and Human Rights are:

1) the obligation of the State to protect human rights in business activities;

2) corporate responsibility for respect for human rights;

3) access to reparation and remediation mechanisms for those who, in this scope, have their rights affected; and

4) the implementation, monitoring and evaluation of the Guidelines (Brasil, 2018). ${ }^{3}$

In tune with this declared co-responsibility, in the beginning of January, the Brazilian Federal Government published an update on the "Dirty List of Slave Labor", which is the register of employers who subjected workers to conditions

${ }^{3}$ Free translation of the Brazilian legal text: “Art. $2^{\circ}$ São eixos orientadores das Diretrizes Nacionais sobre Empresas e Direitos Humanos: 1) a obrigação do Estado com a proteção dos direitos humanos em atividades empresariais; 2) a responsabilidade das empresas com o respeito aos direitos humanos 3) o acesso aos mecanismos de reparação e remediação para aqueles que, nesse âmbito, tenham seus direitos afetados; e 4) a implementação, o monitoramento e a avaliação das Diretrizes". 
analogous to slavery. Such publication is mandatory since the Interministerial Ordinance No. 4 of May 11, 2016. But for three years, the registry was not updated, after an injunction by a Minister of the Brazilian Federal Supreme Court, at the request of an employer.

Only when other Minister assumed the presidency of the Court, the measure was revoked, but still was not published. There followed a legal battle between the Executive and the Public Prosecutor's Office, until the disclosure early this year. The publication of the listing is the responsibility of the Secretariat of Labor Inspection, linked until the end of last year to the extinct Ministry of Labor. Now it has become the responsibility of the newly created Ministry of Economy, to where the inspection body has been transferred. Besides the changes of politic design and in the hierarchy of power the guidelines remain applicable and probably facilitated the publication of the new "Dirty List of Slave Labor".

The list brings 204 names of employers, mostly farms, charcoal shops, extraction areas, sewing workshops and construction sites, from 22 Brazilian states in rural and urban areas, where occurrences of work analogous to slavery were found. The highlights are Minas Gerais, with 55 registered cases, and Pará, with 27. In total, 2463 workers are affected (SIT, 2019).

On the other hand, there are also drawbacks risks. The adoption of the Guidelines has taken to surprise organizations of the civil society that follow the thematic closely. No preliminary version of the text of the decree was made available, nor was it open to consultation for civil society to make contributions to its content, reducing the possibility of people and communities affected or potentially affected by the action of companies. And the broad participation in the process of building the parameters was one of the recommendations made by the UN study group (Conectas, Cruz, Nabuco, \& Nascimento, 2018) mainly because it would facilitate its governance in the future.

And governance is one of the main challenges. A empirical research conducted by Conectas shows that even before the decree there was more than average knowledge about what are the human rights principles to be followed by companies, especially by large and medium corporations, whose activities have greater potential of impact on socio-environmental rights. But the same research points out that there is a lack of institutional rooting, demonstrated by the low number of cases of public human rights policies, with periodic revision of their guidelines or that have mechanisms to evaluate the effective impacts on people and communities affected (Conectas, Cruz, Nabuco, \& Nascimento, 2019).

Another point is that because Brazil had already adopted all the major international documents aimed at the protection of human rights and has been charging diligently many companies' conducts based on these documents and general broad principles, the restriction to voluntary guidelines can represent a drawback especially regarding enforcement. Cases could not be brought to justice based on non-compliance with principles, even to those that Brazil has committed generally in international treaties, this because the decree establishes that the adequacy of the companies to the paradigms is voluntary. 
A recent case relating to the Brazilian coffee production highlights the limitations of voluntary standards. Between June and August 2018, more than 130 workers (Conectas et al., 2019) were rescued from degrading or forced labour in a region not only certified by Starbucks C.A.F.E. Practices (SCS Global Services, 2018) which aim is to ensure ethical sourcing for coffee, but also labelled UTZ, a label for sustainable farming of coffee, cocoa, tea and hazelnuts (UTZ, 2018).

Non profits such as Conectas and ADERE-MG (Articulação dos Empregados Rurais do Estado de Minas Gerais) denounced the case in the Brazilian focal point of the Organisation for Economic Cooperation and Development's guidelines for multinational enterprises (OECD, 2011). The 37 rescued worked that were the base to the OECD complaint was from a region that produces half of the Brazilian coffee what correspond to a third of the global production (Conectas et al., 2019). The farms supplied grains to Nestlé, Jacobs Douwe Egberts, McDonald's, Dunkin' Donuts, Starbucks e Illy (Conectas et al., 2019).

By the literal interpretation of the decree these companies could not be held reliable, if they had not voluntary committed them. Among the violations were: conditions of work similar to slavery, poor housing conditions, food shortages, lack of hygiene in housing and common areas, absence of personal protective equipment, illegal hiring and irregular payments (Conectas et al., 2019: p. 15).

In summary, promising provisions contained in the decree-such as the inclusion of supply chains as potential corporate responsibility violations, priority for reparations and compensation for vulnerable groups, and the need to improve mechanisms for transparency and participation-they are overshadowed by the poorly participatory construction of the document and by the option of adopting an voluntary framework in dealing with corporate human rights obligations (Conectas et al., 2019: p. 28). ${ }^{4}$

Notwithstanding the new political context in Brazil is marked by values questioning. There are cases that came to the extreme of criminalizing some of the civil society work on social movements, academic centres and as activists in general (Homa et al., 2018). And the freedom of opposition has been essential in the history of Human Rights and fundamental guarantees, nationally and internationally. Notwithstanding in this present context the Brazilian Decree can be politically misused to restrain the human rights protections rather than broadening them.

\section{Conclusion}

This paper started by highlighting the governance challenge in place since technology enabled the global value chain production. Then it focused in the corporate responsibility and the necessity of companies being considered part of the ${ }^{4}$ Free translation of the text: "dispositivos promissores que constam nas Diretrizes-como a inclusão das cadeias de fornecimento como possíveis focos de violações sob responsabilidade das empresas, prioridade para reparações e indenizações destinadas a grupos em situação de vulnerabilidade e menção à necessidade de aperfeiçoar mecanismos de transparência e participação-acabam sendo ofuscados pela construção pouco participativa do documento e pela opção em adotar um marco facultativo ao lidar com as obrigações das empresas em matéria de direitos humanos.” 
solution not only the problems. One of the initiatives in this path is the Agenda 2030, but the methodology of goals and incremental gains can disguise techniques of postponing solutions that should be put in place immediately.

Voluntary commitments can be useful, but there is an on-going process of creating an international legally binding instrument to regulate, under international law and the UN, the activities of transnational corporations and other business enterprises with respect to human rights and incorporating the non-legally binding UN Guiding Principles on Business and Human Right.

This initiative is called First Draft and has been created around: prevention; access to justice at the victim's country or where the company is incorporated; international cooperation; monitoring mechanisms; and inspiration from previous human rights treaties. Having the limits clearly stated in legal terms would contribute to avoid what is morally wrong at the same time as promoting transparency to avoid unilateral disproportionate measures that could eventually work as barrier to free trade.

In this context, the Brazilian regulation will frame the business done in Brazil. It has the potential to stimulate compliance and due diligence mechanisms. Therefore, as long as accompanied by a national effort that focuses on the prevention and accountability of companies for human rights violations, it is welcome. But there is a dichotomy intrinsically being carried along that only can be prevented on case-by-case analyses. Society has an important role to demand the new decree when applied brings real progress and not drawbacks to the enforcement of fundamental rights relating to business.

\section{Conflicts of Interest}

The author declares no conflicts of interest regarding the publication of this paper.

\section{References}

Abbott, K. W., \& Snidal, D. (2000). Hard and Soft Law in International Governance. International Organization, 54, 421-456. https://doi.org/10.1162/002081800551280

Acca, T., \& Scabin, F. (2018). Empresas e direitos humanos. Ricardo Alfonsin Advogados Website. https://alfonsin.com.br/empresas-e-direitos-humanos

Baumann-Pauly, D., \& Nolan, J. (2016). Business and Human Rights: From Principles to Practice (1st ed.). Abingdon, New York: Routledge. https://doi.org/10.4324/9781315735429

Brasil, P. da R. (2018). Decreto No 9.571/2018-Estabelece as Diretrizes Nacionais sobre Empresas e Direitos Humanos.

Conectas, D. H., Cruz, J., Nabuco, J., \& Nascimento, J. (2018). Recomendações do grupo de trabalho da ONU sobre empresas e Direitos Humanos ao Brasil: Status da implementação pelo governo e empresas.

https://www.conectas.org/publicacoes/download/recomendacoes-grupo-de-trabalho-d a-onu-sobre-empresas-e-direitos-humanos-ao-brasil-status-de-implementacao-pelo-go verno-e-empresas

Conectas, D. H., Cruz, J., Nabuco, J., \& Nascimento, J. (2019). Segundo relatório de 
acompanhamento das recomendações do grupo de trabalho da ONU sobre empresas e Direitos Humanos ao Brasil: Status da implementação pelo governo e empresas. https://www.conectas.org/publicacoes/download/recomendacoes-grupo-de-trabalho-d a-onu-sobre-empresas-e-direitos-humanos-ao-brasil-status-de-implementacao-pelo-go verno-e-empresas

Denny, D. M. T. (2018a). Agenda 2030 e governança ambiental: Estudo de caso sobre etanol da cana de açúcar e padróes de sustentabilidade como bonsucro. UNISANTOS-Universidade Católica de Santos.

Denny, D. M. T. (2018b). Human Rights and Market Access. Revista de Direito Internacional, 15, 202-220. https://doi.org/10.5102/rdi.v15i2.5277

Global Justice Now (2018). https://www.globaljustice.org.uk

Henson, S., \& Humphrey, J. (2010). Understanding the Complexities of Private Standards in Global Agri-Food Chains as They Impact Developing Countries. The Journal of Development Studies, 46, 1628-1646. https://doi.org/10.1080/00220381003706494

Homa, C. de D. H. e E., Roland, M. C., \& Lima, G. (2018). Homa analia o Decreto 9571/2018 que estabelece Diretrizes Nacionais para empresas e Direitos Humanos. http://homacdhe.com/index.php/2018/12/27/homa-publica-analise-do-decreto-957120 18-que-estabelece-diretrizes-nacionais-para-empresas-e-direitos-humanos

HRC, Human Rights Council (2011). Guiding Principles on Business and Human Rights: Implementing the United Nations "Protect, Respect and Remedy" Framework.

ILO (1919). Labour Standards. http://www.ilo.org/global/standards/lang--en/index.htm

ILO (2017). World Employment and Social Outlook: Trends 2017. http://www.ilo.org/wcmsp5/groups/public/---dgreports/---dcomm/---publ/documents/ publication/wcms_541211.pdf

Kessie, E., \& UNCTAD (2003). Módulo 3.4 Implementação e Execução do Curso de Solução de Disputas em Comércio Internacional, Investimentos e Propriedade Intelectual (Kanas, V., Trans.). http://unctad.org/pt/docs/edmmisc232add23_pt.pdf

Nieuwenkamp, R. (2013). The OECD Guidelines for Multinational Enterprises on Responsible Business Conduct. Dovenschmidt Quarterly, 2013, 171.

OECD (2011). Organisation for Economic Co-Operation and Development Guidelines for Multinational Enterprises.

OHCHR (2018). OHCHR Accountability and Remedy Project Improving Accountability and Access to Remedy in Cases of Business Involvement in Human Rights Abuses Phase III: Enhancing the Effectiveness of Non-State-Based Grievance Mechanisms Scope and Programme of Work. https://www.ohchr.org/Documents/Issues/Business/ARP/ARPIII-PoW.pdf

Pogge, T. W., Kaul, S., Kim, D., Västfjäll, D., \& Slovic, P. (2015). Imagining Human Rights. https://www.researchgate.net/publication/285701999_The_progressive_potential_of_h uman_rights

Pogge, T., \& Sengupta, M. (2016). Assessing the Sustainable Development Goals from a Human Rights Perspective. Journal of International and Comparative Social Policy, 32, 83-97. https://doi.org/10.1080/21699763.2016.1198268

Ren, Y. (2018). The Theoretical System of Human Rights with Chinese Characteristics. Chinese Studies, 7, 210-219. https://doi.org/10.4236/chnstd.2018.73018

Rivera, H. C. (2018). Some Remarks on the Third Session of the Business and Human Rights Treaty Process and the "Zero Draft." Revista de Direito Internacional, 15, 24-40. https://doi.org/10.5102/rdi.v15i2.5696

SCS Global Services (2018). Starbucks C.A.F.E. Practices Ensuring Ethical Sourcing for 
Coffee. https://www.scsglobalservices.com/services/starbucks-cafe-practices

SIT (2019). Lista Suja-Cadastro de Empregadores que tenham submetido trabalhadores a condições análogas à de escravo-Portaria Interministerial MTPS/MMIRDH no 4 de 11/05/2016, atualizada 24 de janeiro de 2019.

Thorstensen, V. H., \& Badin, M. R. S. (2017). Coerência e convergência regulatória no comércio exterior: $O$ caso do Brasil frente a União Europeia e Estados Unidos com ênfase na experiência do Reino Unido: Volume 1: Coerência regulatória. Technical Report. Centro de Estudos do Comércio Global e Investimento (CCGI) Website. http://bibliotecadigital.fgv.br/dspace/handle/10438/18731

Thorstensen, V. H., Kotzias, F. V., \& Vieira, A. (2015). A ameaça dos padróes privados à $O M C$. International Centre for Trade and Sustainable Development.

http://www.ictsd.org/bridges-news/pontes/news/a-amea\%C3\%A7a-dos-padr\%C3\%B5e s-privados-\%C3\%A0-omc

UN (1948). Universal Declaration of Human Rights. Pub. L. No. A/811.

UN (1966a). International Covenant on Civil and Political Rights.

UN (1966b). International Covenant on Economic, Social and Cultural Rights.

UN (2015). Agenda 2030.

http://www.un.org/ga/search/view_doc.asp?symbol=A/RES/70/1\&Lang=E

UNCTAD (2003). Article XX General Exceptions, Interpretation and Application of Article XX. Course on Dispute Settlement in International Trade, Investment and Intellectual Property. http://unctad.org/en/Docs/edmmisc232add33_en.pdf

UNCTAD (2018). Trade and Development Report 2018.

https://unctad.org/en/pages/PublicationWebflyer.aspx?publicationid=2227

UTZ (2018). Label and Program for Sustainable Farming of Coffee, Cocoa, Tea and Hazelnuts. UTZ Website. https://utz.org 